\title{
The Effect of Various Processing Methods on Ease of Removal of More than Half the Silver Skin from Green Coffee Beans
}

\author{
D. S. Boyce
}

\section{INTRODUCTION}

With the advent of new and modern methods of coffee-processing unexpected factors affecting the ultimate product are becoming evident. As an example, it has recently been reported that coffee parchment which has been mechanically demucilaged and artificially dried appeared to yield, after hulling, samples of green beans with a high percentage of silver skin tenaciously adhering to them. It was consequently of interest to determine whether or not this could be verified and also which factors in the processing cycle were responsible.

A simple experiment was therefore designed to determine whether there was any significant difference in the removal of silver skin from coffee processed by means of mechanically or naturally fermented demucilaging, and dried either by artificial means or by the sun.

\section{REVIEW OF THE LITERATURE}

There does not seem to have been any previous consideration given to this specific problem, although Goto and Fukunaga $(1)^{2}$ reported from Hawaii that:

The silver skin on some coffee comes off more easily than others. The silver skin on coffee grown at lower elevations in Kona, for example, is generally harder to remove than is the skin on coffee grown in the upper areas. In the past the silver skin was rubbed off the bean with special polishers. This is not done very much today, however, since it was found that the silver skin did not affect the quality of the roasted coffee.

Haaer (2), referring to East Africa stated:

The term immature and "coated bean" refers to light, starved beans badly coated with silver skin. This can be due to several causes, and there are some regions in

${ }^{1}$ Lecturer, Department of Agricultural Engineering, College of Agriculture and Mechanic Arts, Mayagüez, P. R. The author wishes to acknowledge the cooperation of General Manager Antonio Natali, of the Cooperative Agricultural Industries of Puerto Rico Factory, Maricao, for supplying samples of coffee parchment; of Saulo Rodriguez Ortiz, Assistant Agronomist in Charge of the Castañer Agricultural Substation, for suggesting the problem and supplying samples; and of Rene Otero, Research Assistant, Agricultural Engineering Department, who carried out the laborasory work involved in collecting the experimental data.

2 Italic numbers in parentheses refer to Literature Cited, p. 131. 
particular, which produce coffee that tends to retain its silver skin closely adhering to the bean.

Thus the literature concerned with the problem of the adherence of the silver skin to the bean indicates that it is influenced specifically by regional differences, though other unstated factors are also considered to be partly responsible. Nevertheless, it does not appear that this condition has ever been specifically associated with methods of preparation. It also appears that, though this condition was given considerable importance in the past, it is now regarded as not so important.

\section{EXPERIMENTAL PROCEDURE}

Four different treatments, each replicated 6 times and containing 400 beans per replication, were used as indicated below. Each replication was hulled and visually examined to determine the percentage of green beans from which 50 percent or more of the silver skin could be easily removed by manipulating the bean between the fingers, and it was found that either a large portion of the silver skin was easily removed or that it tenaciously adhered to the bean in its entirety. The four treatments are as follows:

1. Naturally fermented and artificially dried (rotary drier) coffee from the Cooperative Agricultural Industries of Puerto Rico's Factory, Maricao.

2. Naturally fermented (laboratory) sun-dried parchment from the Coffee Factory of the Castaner Substation.

3. Mechanically demucilaged (Hess machine) (l) and sun-dried parchment from the Coffee Factory of the Castañer Substation.

4. Mechanically demucilaged (Hess machine) and artificially dried (rotary drier) parchment from the Coffee Factory of the Castañer Substation.

\section{EXPERIMENTAL RESULTS}

The purpose of the statistical analysis was to determine whether the ease of removal of the silver skin was affected by:

1 , Method used in demucilaging

A, Natural fermentation

B, Mechanical demucilaging (Hess machine)

2, Method used in drying

A, Natural sun-drying

$B$, Artificial drying (rotary drier)

3, Interaction between main effects 1 and 2 .

It can be seen in the following tabulation, which summarizes the results derived from various combinations of the two methods of drying and the two methods of demucilaging, that the treatment employing natural fermentation and artificial (rotary drier) drying gave significantly better 
results than any of the other three treatments at the 0.01-percent level, there being no significant difference between the latter:

\section{Demucilaging $\times \quad$ Drying}

Natural fermentation $\times$ Artificial (rotary drier)

Do. $\quad \times$ Natural (sun-dried)

Mechanical (Hess)

Do. do.

$\times$ Artificial (rotary drier)

Mean percentage of beans

62.50

27.66

19.33

15.83

24.12

17.62

Minimum significant difference between the means at:

1 percent-level

5 percent-level

Table 1 shows calculated $F$ values and table readings for the two main effects considered and their interaction. It can be seen that demucilaging

TABLE 1.-F values, calculated, and lable readings for the 2 main effects and their interaction

\begin{tabular}{l|c|c|c}
\hline \multirow{2}{*}{ Factor } & $F$ (by calculation) & \multicolumn{2}{|c}{ Reading of $F$} \\
\cline { 2 - 3 } & & $P=0.05$ & $P=0.01$ \\
\hline Demucilaging & 21.07 & 4.35 & 8.10 \\
Drying & 6.84 & 4.35 & 8.10 \\
Demucilaging and drying & 10.24 & 4.35 & 8.10 \\
\hline
\end{tabular}

is the most important factor affecting the ease of removal of the silver skin, being significant at the 0.01-percent level; that drying is significant at the 0.05-percent level; and that the interaction between the two effects is significant at the 0.01-percent level.

\section{SUMMARY AND CONCLUSIONS}

It has been shown that the methods utilized to process coffee cherries to dry coffee parchment affect to a considerable extent the ease with which the silver skin may be removed from the green coffee bean subsequently. Natural fermentation is significantly more effective at the 0.01 probability level in producing a sample with an easily removable silver skin than mechanical demucilaging with the Hess machine. Artificial drying produces a sample from which the silver skin can be more easily removed than natural drying at the 0.05 probability level. Furthermore, there was significance at the 0.01 probability level when the interaction between the two main effects of drying and demucilaging were considered.

In considering the interaction of the two main effects it was found that 
natural fermentation combined with artificial (rotary-drier) drying produced the most favorable results. It was significantly greater than any of the other three possible combinations at the 0.01-percent probability level and there was no significant difference between the latter three. This lack of significance may be attributed, in part, to possible negative interaction between the two main effects, that is, in certain combinations the two main effects may have the effect of causing the silver skin to adhere tenaciously to the bean.

\section{RESUMEN}

Se ha demostrado que los métodos que se usan para beneficiar el grano maduro de café hasta convertirlo en café pergamino afectan la facilidad con que se desprende la epidermis plateada del grano verde comercial. La epidermis del grano fermentado naturalmente se desprende con mayor facilidad al nivel de probabilidad de 0.01 que cuando se le quita el mucílago a dichos granos mecánicamente con una máquina Hess.

El secado artificial produce muestras de las cuales la epidermis plateada puede quitarse con mayor facilidad, a una probabilidad de 0.05 , que la epidermis plateada de las que se secan naturalmente. La interacción de los dos efectos principales, secado y demucilaginación, fué significativa al nivel de probabilidad de 0.01 .

Cuando se consideró la interacción de los dos efectos principales mencionados se encontró que la fermentación natural combinada con la artificial (secadora rotatoria) produjo los mejores resultados. Fué significativamente mayor que cualquiera de las otras posibles combinaciones al nivel de probabilidad de $0.01 \mathrm{y}$ no hubo diferencia significativa entre las últimas tres combinaciones.

Esta falta de significancia puede atribuírse, en parte, a la posible interacción negativa entre los dos efectos principales, esto es, en ciertas combinaciones los dos efectos principales pueden causar que la epidermis plateada se adhiera más tenazmente al grano.

\section{LITERATURE CITED}

1. Goto, Baron Y., and Fukunaga, Edward T., Coffee Harvesting and Processing for Top Quality Coffee, Ext. Cir. 359, Univ. of Hawaii, pp. 13 and 19, 1956.

2. Haaer, A. E., Modern Coffee Production, p. 266, Leonard Hill (Books) Ltd., London, England, 1956. 